\title{
The Effect of Carboxymethyl Chitosan on Calcium Carbonate Precipitation in Synthetic Brines
}

\author{
Genaro Bolívar $^{1}$, Marinela Colina ${ }^{2}$, Blas Delgado $^{3}$, Eduardo Mendizabal $^{1}$ \\ ${ }^{1}$ Centro Universitario de Ciencias Exactas e Ingenierías, Universidad de Guadalajara, Blvd. Gral. Marcelino \\ García Barragán 1421, Olímpica, 44430 Guadalajara, Jalisco, México. \\ ${ }^{2}$ Innovación Ambiental Quitosano C.A. (INNOVAQUITO C.A.). Av. 4 San Francisco No 29-25 Sector San \\ Benito. Maracaibo. Venezuela. \\ ${ }^{3}$ Área de Análisis Químico Inorgánico. PDVSA. INTEVEP. Los Teques 1070-A, Venezuela.
}

*Corresponding author: Genaro Bolívar, email: : genaro.bolivar@alumnos.udg.mx; Tel.: + 5213326568243

Received August 16 ${ }^{\text {th }}, 2020$; Accepted November 10 $0^{\text {th }}, 2020$.

DOI: http://dx.doi.org/10.29356/jmes.v65i1.1429

\begin{abstract}
When oil production by natural flow of reservoirs decreases, it is necessary to increase the production by using improved recovery processes, such as water injection. Injection of incompatible water can cause the formation of saline deposits of calcium and magnesium carbonates. The use of chemical inhibitors to treat incrustations involves the use of chemicals with functional groups such as carboxylic acids (R-COOH) or phosphonates $\left(\mathrm{R}-\mathrm{PO}_{3}{ }^{2-}\right)$. A new ecological scale inhibitor, carboxymethyl chitosan (CMC1), has been synthesized and its capacity to modify the $\mathrm{CaCO}_{3}$ crystalline phases obtained in the solid residue was compared with that obtained when using a commercial carboxymethyl chitosan (CMC2) and a commercial poly(acrylic acid). The results show that under the used conditions, the $\mathrm{CMC}^{\prime}$ 's produce a slightly larger amount of crystalline phases than the synthetic inhibitor. Using the $\mathrm{X}$-ray powder diffraction technique, calcite, vaterite, and aragonite were identified in the residual solid. The ratio of these phases was modified by increasing the concentration of the inhibitor. Using Scanning Electron Microscopy (SEM), it was observed that increasing the concentration of the CMC's the modifies the crystal's morphology from plates to spheres.

Keywords: X-ray diffraction; scanning electron microscopy; optical emission spectroscopy of inductively coupled plasma (ICP); scale inhibitor; carboximethyl chitosan.

Resumen. Cuando la producción de petróleo por flujo natural disminuye, es necesario aumentar la producción de petróleo crudo y gas mediante procesos de recuperación mejorados. El agua es el líquido que se inyecta y puede provocar la formación de depósitos salinos de carbonato de calcio y magnesio. El uso de inhibidores químicos para el tratamiento de incrustaciones implica el empleo de productos químicos con grupos funcionales del tipo ácido carboxílico (R-COOH) o grupos fosfonatos $\left(\mathrm{R}^{-} \mathrm{PO}_{3}{ }^{2-}\right)$. Se sintetizó un nuevo inhibidor de incrustaciones ambientalmente amigable en base a carboximetilquitosano (CMC1), y se compararon las fases cristalinas de $\mathrm{CaCO}_{3}$ obtenidas en el residuo sólido con las obtenidas al utilizar un carboximetilquitosano comercial (CMC2) y un poli (ácido acrílico) comercial. Los resultados muestran que, en las condiciones utilizadas, las CMC producen una cantidad ligeramente mayor de fases cristalinas en comparación con el inhibidor sintético. Mediante la técnica de difracción de rayos X de polvos, en el sólido residual se identificaron las fases: Calcita, Vaterita y Aragonita. La relación de las fases se modificó aumentando la concentración del inhibidor. Mediante Microscopía Electrónica de Barrido (SEM) de los residuos sólidos, se observó que al aumentar la concentración de las CMC's la morfología de los cristales se modificaba de placas a esferas.
\end{abstract}


Palabras clave: Difracción de rayos X (DRX); microscopia electrónica de barrido (MEB); espectroscopia de emisión atómica con plasma inductivamente acoplado (ICP); inhibidor de incrustaciones; carboximetil quitosano.

\section{Introduction}

Due to the extensive use of water injection for oil displacement and pressure maintenance in oilfields, many reservoirs experience the problem of scale deposition when water injection starts. In most cases, the scale is caused by the formation of calcium and strontium carbonate and sulfate salts [1]. The consequences of scale deposition can be delayed production, failure of production equipment, unscheduled shutdowns, increased maintenance costs and decreased production efficiency [2]. Scale deposits could also plug the pores of the formation in injection wells, resulting in injectivity decline [3]. The scales commonly found in the deposit are carbonates $[1,4]$. While the formation of carbonate incrustations is associated with changes in pressure and temperature that favor precipitation of salts present in the water, the appearance of sulfate incrustations is mainly due to the mixing of incompatible waters to maintain pressure or to flooding strategies [2].

Scale prevention is achieved by the scale-inhibitor squeeze technique. A key factor in the success of such treatments is the understanding of the chemical mechanism of the treatment [5]. The most common chemical inhibitors are synthetic inorganic phosphates, organophosphorus compounds and organic polymers (poly(acrylic acids). With the need to conserve the environment, recent legislation is promoting the use of ecological inhibitors in all industries, including the oil and gas industry [6]. Recently, carboxymethyl chitosan has been studied in different areas of the oil industry: for the extraction of nickel and vanadium from crude oil [7], treatment of oil spills [8] and as scale inhibitors [9]. This paper focuses on comparing the morphology and type of crystals obtained in the solid residue when using a new generation of eco-friendly scale inhibitors, carboxylated chitosan and poly (acrylic acid) (commercial synthetic additive).

\section{Experimental}

\section{Synthesis of the modified Carboxymethyl Chitosan (CMC)}

Shrimp-shell-derived chitosan, purchased from INNOVAQUITO C.A. (Venezuela), was used as starting material for the preparation of a chitosan derivative (CMC1). The CMC1 was prepared according to the method described by Zhu et al. [10] to generate carboxyl groups in the backbone of the chain.

A $6.8 \mathrm{~g}$ portion of sodium hydroxide was dissolved in $10 \mathrm{~mL}$ of water, and $40 \mathrm{~mL}$ of 2-propanol was added to the solution. Then $5.0 \mathrm{~g}$ of chitosan was dispersed into the solution and stirred at $50{ }^{\circ} \mathrm{C}$ for $1 \mathrm{~h}$. After that, $7.5 \mathrm{~g}$ of monochloroacetic acid in $10 \mathrm{~mL}$ of 2-propanol was added to the mixture dropwise and the reaction was carried out at $50{ }^{\circ} \mathrm{C}$ for $4 \mathrm{~h}$. The resulting solution was filtered, washed with $80 \%$ alcohol and $20 \%$ water until the filtrate was neutral, and then dried in an oven to obtain CMC.

The other carboxymethyl chitosan tested (CMC2) was supplied by Shanghai Hanshare Industry Co., LTD from China. Both CMC`s were characterized by GPC, and the degree of COOH substitution (DS) and the $\mathrm{pK}_{\mathrm{a}}$ 's of the CMC's were determined by potentiometric titration (Fig. 2). To obtain DS equation (1) was used [11], [9].

$$
D S=\frac{161 x A}{m_{c m c}-58 x A}
$$

where:

$$
\begin{aligned}
& \mathrm{A}=\text { moles of } \mathrm{NaOH} \\
& \mathrm{m}_{\mathrm{cmc}}=\mathrm{CMC} \text { mass }
\end{aligned}
$$




\section{Scale inhibitor tests}

Synthetic brines were prepared following the standard laboratory test method NACE - TM 0374, 2007 (Table 1). The quantification of ions in solutions was measured before and after precipitation by inductively coupled plasma optical emission spectroscopy (ICP OES).

Table 1. Ions concentration in synthetic brine determined by inductively coupled plasma atomic emission spectrometry.

\begin{tabular}{|c|c|}
\hline Ion & $\begin{array}{c}\text { Concentration } \\
\text { ppm }\end{array}$ \\
\hline $\mathrm{Ca}^{2+}$ & 3313 \\
\hline $\mathrm{Mg}^{2+}$ & 437 \\
\hline $\mathrm{Na}^{+}($from $\mathrm{NaCl})$ & 21354 \\
\hline
\end{tabular}

\section{X-Ray analysis}

The precipitates were analyzed by X-ray diffraction technique (DRX). To identify the crystalline phases the ICDD PDF + 42013 crystallographic database of polymorphic calcium carbonate species (01-0862334 Calcite / 01-089- 1304 Calcite-magnesium, 00-033-0268 Vaterite and 01-075-9987 Aragonite) was used.

\section{Results and discussion}

\section{Synthesis of the Carboxymethyl Chitosan (CMC)}

The average molecular weight (MW) was $266,000 \mathrm{~g} / \mathrm{mol}$ for CMC1 and 260,000 g/mol for CMC2 (Fig 1). The molecular weight distribution (MWD) of the $\mathrm{CMC} 2$ was bimodal.

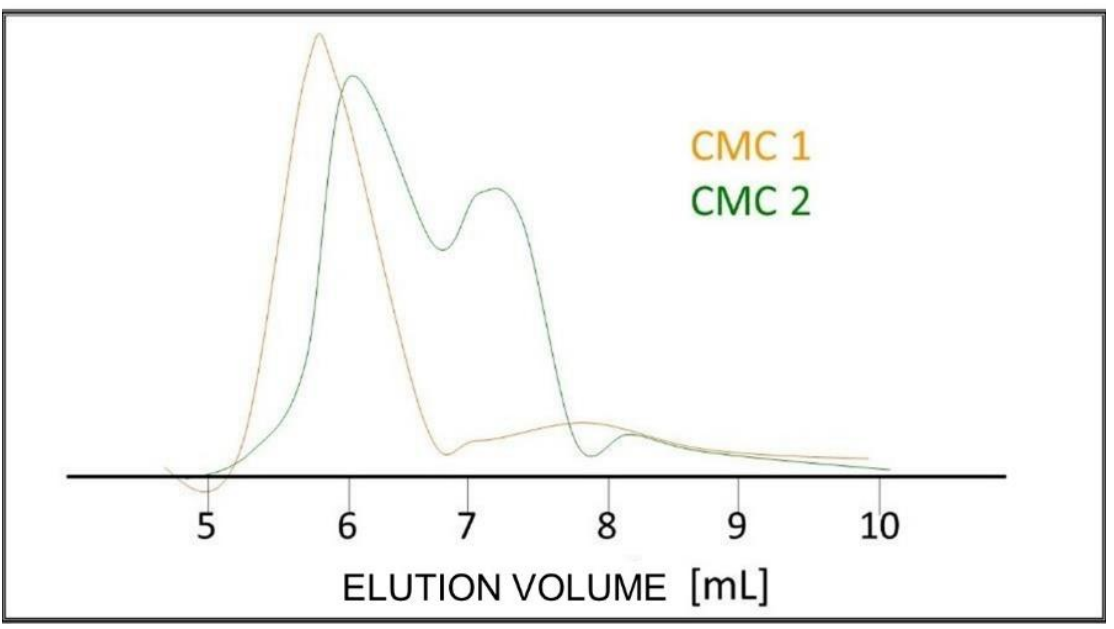

Fig. 1. Molecular weight and molecular weight distribution of the CMC's.

Fig. 2 shows the potentiometric titration curves of CMC's and poly(acrylic acid). From these results, it was obtained that $\mathrm{CMC} 2$ has a DS of $40 \%$ and a $\mathrm{pK}_{\mathrm{a}}=4.6$; the $\mathrm{CMC} 1$ synthesized here has a DS of $23 \%$ and a $\mathrm{pK}_{\mathrm{a}}=5$. The poly (acrylic acid) has a $\mathrm{pK}_{\mathrm{a}}=4.36$. At $\mathrm{pH}=7.0$, practically all the carboxylic groups are found as their conjugate base $\left(\mathrm{COO}^{-}\right)$which is responsible for capturing the metal ions by electrostatic interactions. 

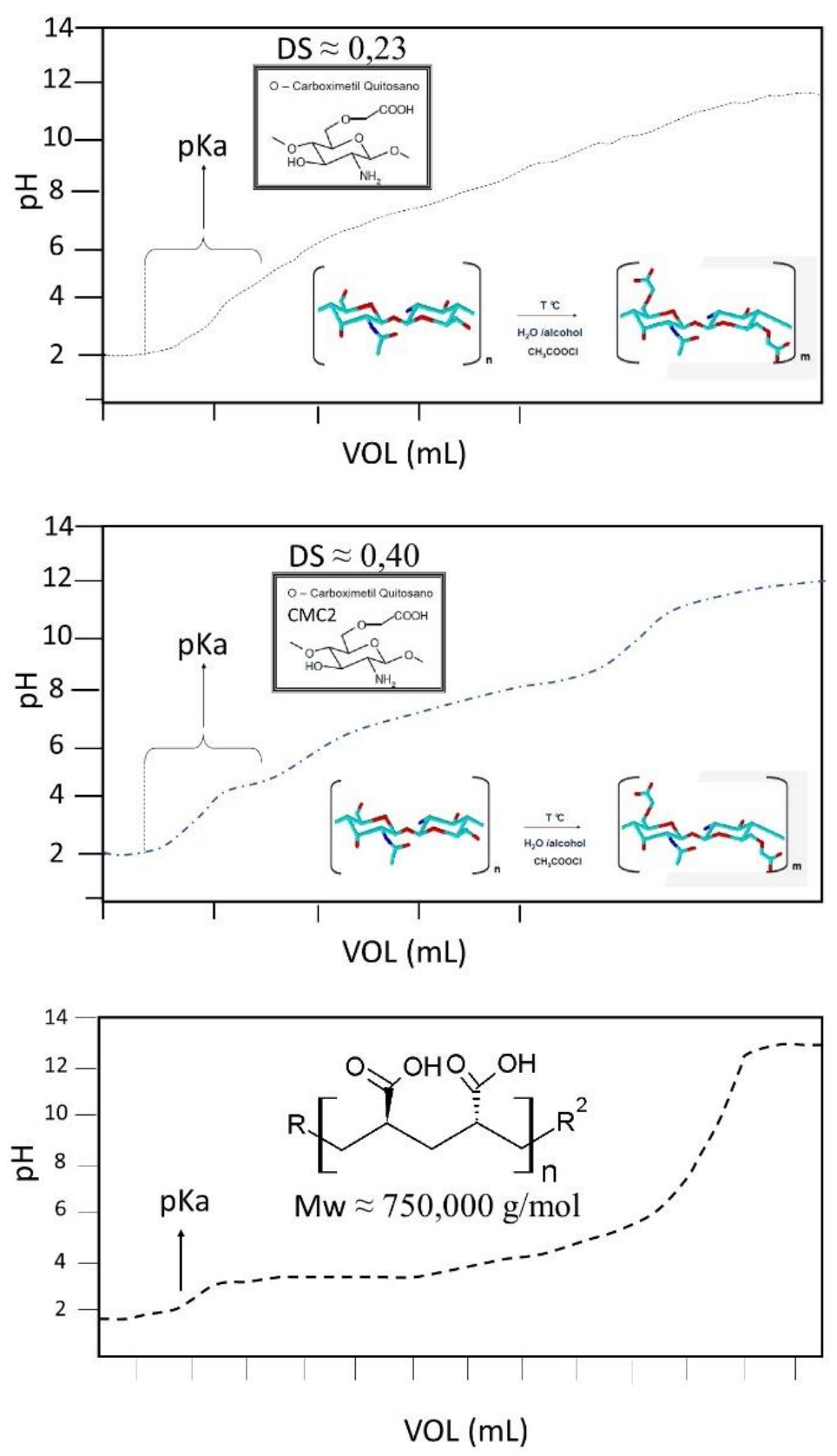

Fig. 2. Potentiometric titration of $\mathrm{CMC}^{\prime} \mathrm{s}((\mathbf{a})=\mathrm{CMC} 1 ;(\mathbf{b})=\mathrm{CMC} 2)$ and poly (acrylic acid $)$.

\section{Scale precipitation test}

The scale inhibitors commonly used in the oil industry are poly(acids) and synthetic phosphonates. They are often applied continuous injection or downhole "squeezing" treatments [12].

Table 2 shows the ions present in the brine solution after the inhibitor treatment, and Fig. 3 shows the percentage of $\mathrm{Ca}^{+2}$ and $\mathrm{Mg}^{+2}$ precipitated when an inhibitor concentration of $0.1 \% \mathrm{w} / \mathrm{w}$ is used. Both CMC's remove a higher percentage of $\mathrm{Ca}^{+2}$ and $\mathrm{Mg}^{+2}$ ions compared to poly(acrylic acid). The higher degree of $\mathrm{COO}^{-}$ substitution (DS) and the higher molar mass of the CMC2 explain the larger amount of $\mathrm{Ca}^{+2}$ and $\mathrm{Mg}^{+2}$ removed 
compared with CMC1. [13]. It has been reported that polymer with higher molecular weight (MWD) have greater capacity to remove $\mathrm{Ca}^{+2}$ compared with polymers with lower MW [14].

Table 2. $\mathrm{Ca}^{2+}$ and $\mathrm{Mg}^{+2}$ ions present in the brine solution after the inhibitor treatment.

\begin{tabular}{|c|c|c|c|c|}
\hline Inhibitor & $\begin{array}{c}\mathbf{C a}^{2+} \\
\mathbf{p p m}\end{array}$ & $\begin{array}{c}\mathbf{M} \mathbf{2}^{\mathbf{2 +}} \\
\mathbf{p p m}\end{array}$ & $\begin{array}{c}\text { \% removed } \\
\mathbf{C a}^{\mathbf{2 +}}\end{array}$ & $\begin{array}{c}\text { \% removed } \\
\mathbf{M g}^{2+}\end{array}$ \\
\hline CMC1 & 658 & 203 & 80 & 54 \\
\hline CMC2 & 377 & 185 & 89 & 58 \\
\hline Poly (acrylic acid) & 807 & 205 & 76 & 47 \\
\hline
\end{tabular}

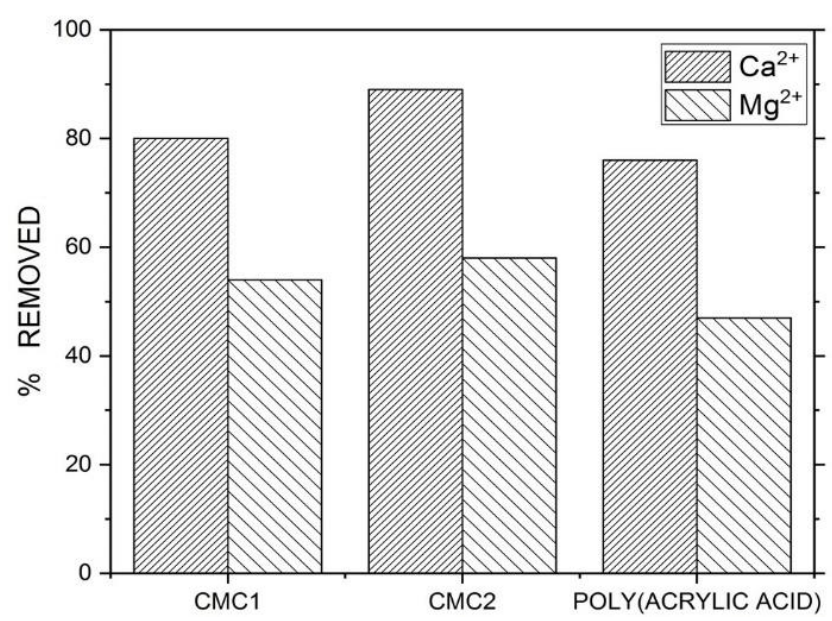

Fig. 3. Percentage of $\mathrm{Ca}^{2+}$ and $\mathrm{Mg}^{2+}$ precipitated from the brine solutions by the CMC's and by the poly(acrylic acid).

\section{Crystalline Phases}

Using the library of the X-Ray diffraction equipment were identified the different crystalline phases of the $\mathrm{CaCO}_{3}$. The XRD diffraction patterns (Fig. 5 and 6) show that the particles obtained when using the CMC's are mixtures of vaterite (JCPDS PDF: 00-033-0268), calcite (JCPDS PDF: 01-086-2334), calcitemagnesium (JCPDS PDF: 01-089- 1304) and aragonite (JCPDS PDF: 01-075-9987). The molar contents (\%)

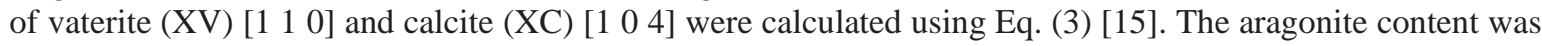
determined using the relative areas of the aragonite [2 21 [ [16].

$$
X_{V}=\frac{7.69 I_{V}^{110}}{I_{C}^{104}+7.691 I_{V}^{110}} ; \quad X_{C}=1-X_{V}
$$

Fig. 4 shows the $\mathrm{CaCO}_{3}$ XRD diffractrograms obtained by using the three inhibitors at different concentrations $(0,1$ to $2 \% \mathrm{w} / \mathrm{w})$. Using the XRD diffractrograms of Fig. 4, the change on concentrations of CMC's that generate significant modification effects on the crystalline phases of $\mathrm{CaCO}_{3}$ were selected $(0.1$ and $2.0 \%$ ), and the effect of the concentration on the distribution of the crystalline phases was determined. 


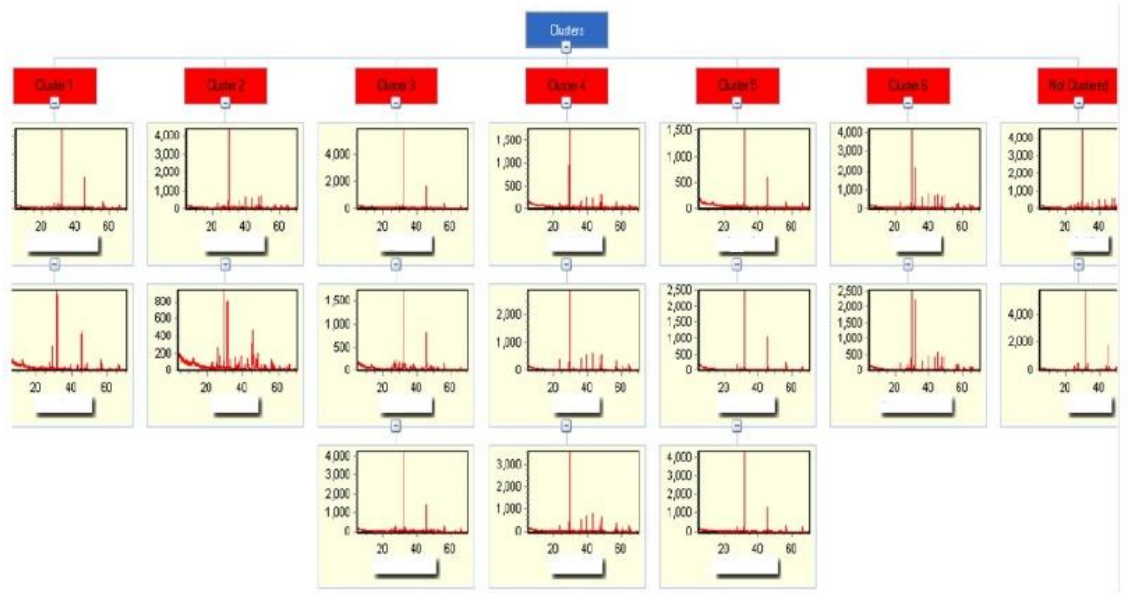

Fig. 4. Illustration of the diagram used to select the concentrations of the CMC that generate significant modification on the crystalline phases of the $\mathrm{CaCO}_{3}$.

Fig. 5 shows that when the CMC's were used at a concentration of $0.1 \%$, the $\mathrm{CaCO}_{3}$ crystals were a mixture of calcite, vaterite, and a small amount of aragonite. Poly(acrylic acid) only generates the thermodynamically stable crystalline phase of $\mathrm{CaCO}_{3}$ (Calcite).
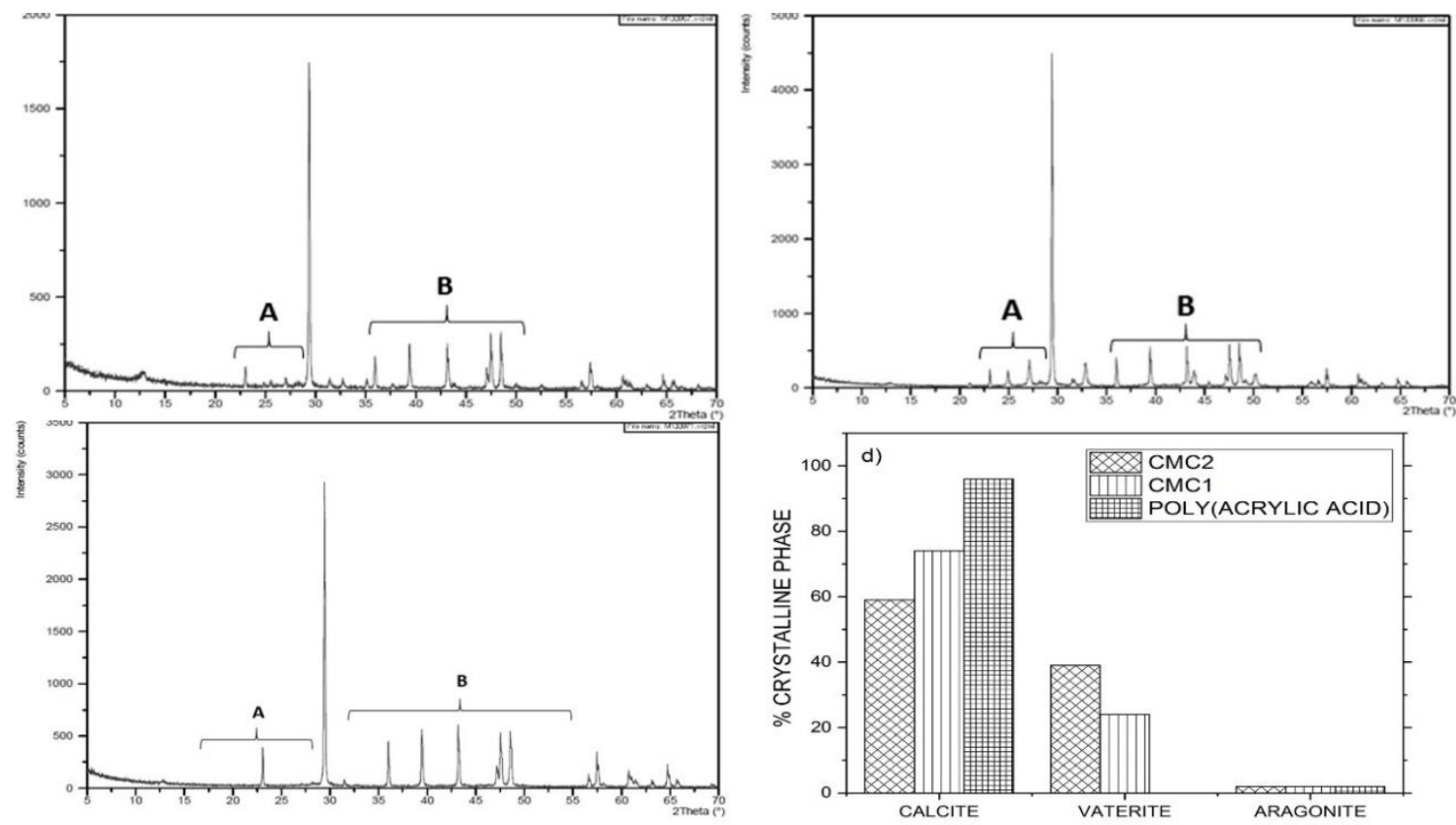

Fig. 5. XRD diffractogram patterns of $\mathrm{CaCO}_{3}$ particles precipitated using $0.1 \%$ inhibitor solutions. (a) $\mathrm{CMC} 1$; (b) CMC2; (c) poly (acrylic acid); (d) distribution of the crystalline phases.

When the concentration of the inhibitors was increased to $2 \%$, the distribution of the crystalline phases of $\mathrm{CaCO}_{3}$ was modified (Fig. 6). Using $\mathrm{CMC} 2$, almost all the crystals were vaterite, while with $\mathrm{CMC}$, the 
crystals belonged mostly to aragonite and calcite. When poly(acrylic acid) was used, most of the crystals were calcite.
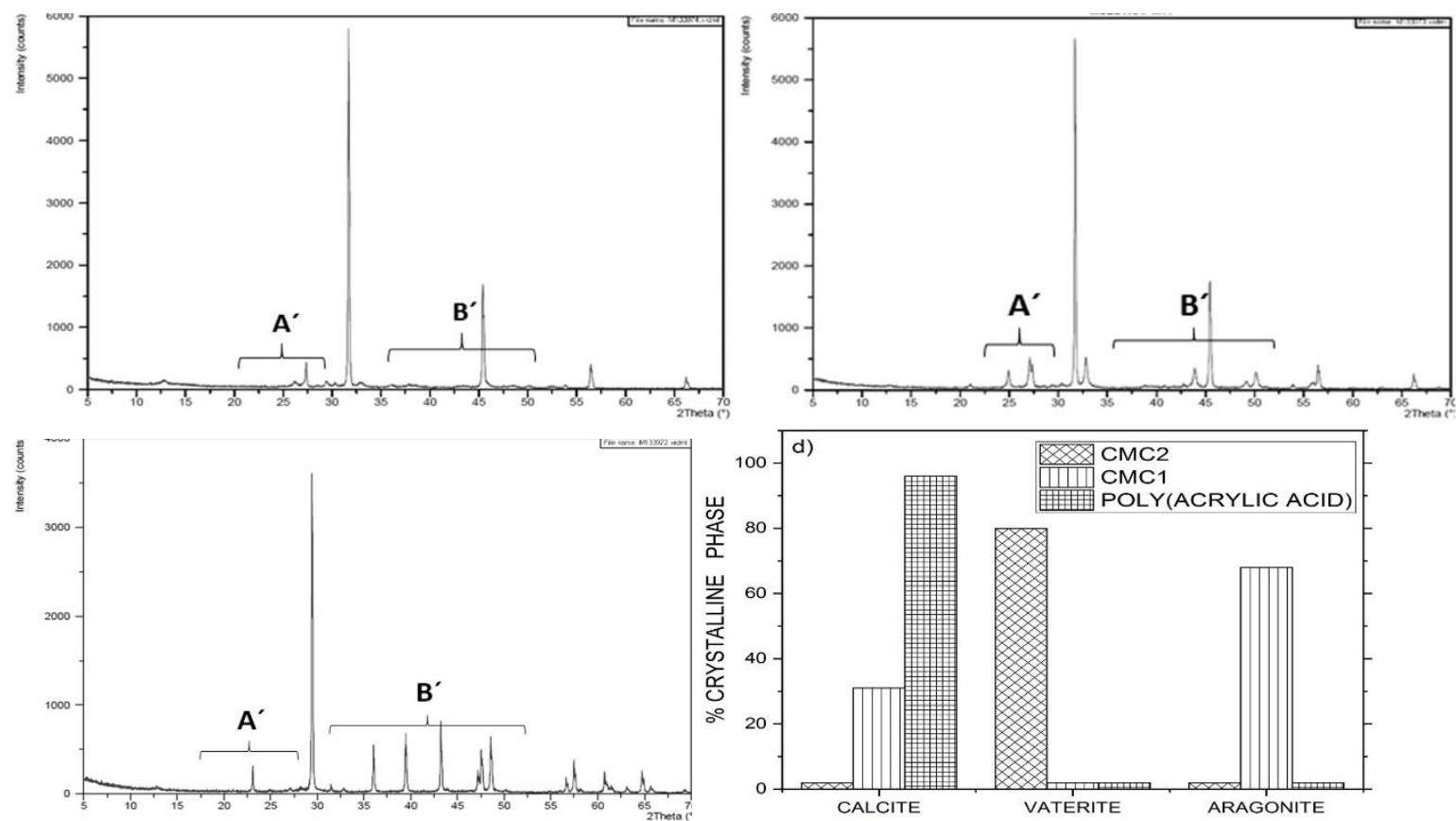

Fig. 6. XRD diffractogram patterns of $\mathrm{CaCO}_{3}$ particles precipitated using $2.0 \%$ inhibitor solutions. (a) $\mathrm{CMC1}$; (b) $\mathrm{CMC2}$; (c) poly (acrylic acid); (d) distribution of the crystalline phases.

Yang. et al. (2010) [15] reported that the presence of CMS modifies the distribution of crystalline phases due to the modulation caused by $\mathrm{CMC}$ molecules on the crystallization of $\mathrm{CaCO}_{3}$ nanocrystals. Because of the slow diffusion of $\mathrm{CO}_{2}$, the formation of $\mathrm{CO}_{3}{ }^{-2}$ is also slow, which makes the interaction between $\mathrm{Ca}^{+2}$ and $-\mathrm{COO}^{-}$more likely than between $\mathrm{Ca}^{+2}$ and $\mathrm{CO}_{3}^{-2}$, which explains the modulation of $\mathrm{CMC}^{\prime} \mathrm{s}$ on the crystallization of $\mathrm{CaCO}_{3}$. A higher DS value generates a higher charge density in synthetic brines, promoting greater repulsion and attraction of charges in the medium, this is one of the contributions of CMC by interfering with the "heterogeneous nucleation" process described previously [6]. This "nucleation inhibition" mechanism contributes to mitigating scale formation because it causes crystal disruption and reduces particle size without affecting the permeability of the [6] reservoir.

\section{Effect of the concentration of inhibitors on $\mathrm{CaCO}_{3}$ morphology}

The size and morphology of $\mathrm{CaCO}_{3}$ precipitates were characterized by an environment HITACHI field-emission scanning electron microscopy (SEM). Fig. 7 shows that when the CMC's concentration is $0.1 \%$, laminar type crystals are formed which are smaller than those obtained when using the poly(acrylic acid). In the micrography of CMC2 in Fig. 7(b), a smaller number of spherical particles of the crystalline phase vaterite can be observed that in that of the CMC1 (Fig. 7(a)). 

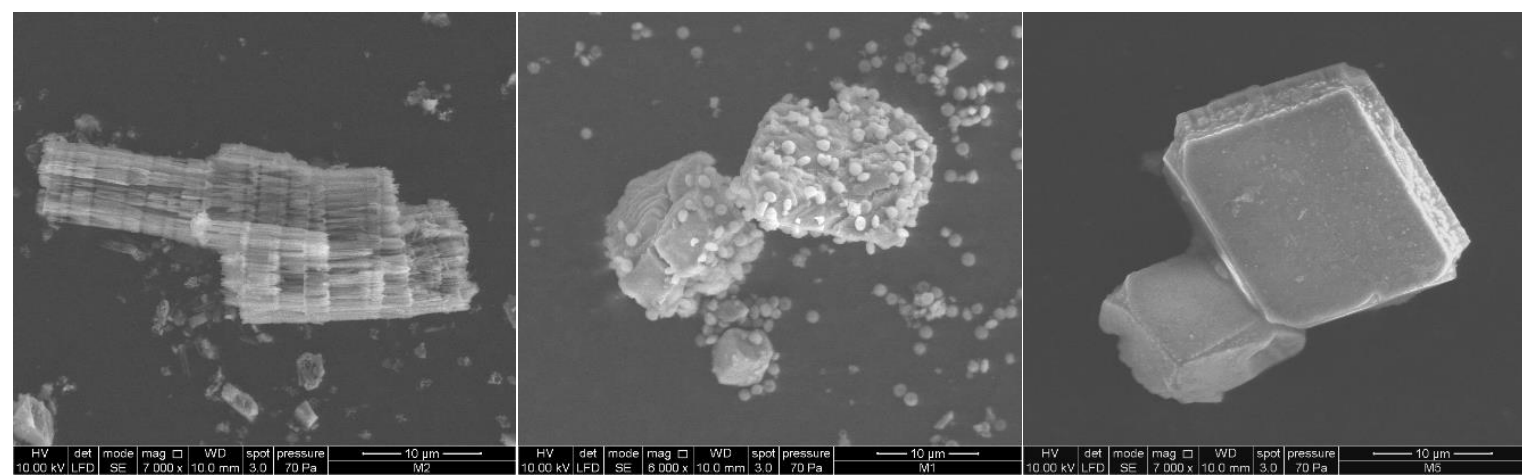

Fig. 7. Micrographs of the $\mathrm{CaCO}_{3}$ crystals obtained when using $0.1 \%$ of inhibitor: (a) $\mathrm{CMC} 1$; (b) $\mathrm{CMC} 2$; (c) poly (acrylic acid).

When the concentration of CMC's was increased to $2 \%$, particle size had increased and the morphology distribution of the $\mathrm{CaCO}_{3}$ crystals was modified, and most of the particles have a spherical shape (vaterite) (Fig. 8). [6]. The interaction between $\mathrm{Ca}^{+2}$ and the $-\mathrm{COO}-$ of the ecofriendly scale inhibitors (CMC's) retards the transition of the metastable $\mathrm{CaCO}_{3}$ (such as vaterite or aragonite) to calcite Also, in the presence of CMC's, the $\mathrm{Ca}^{+2}$ ions form $\mathrm{CMCS} / \mathrm{Ca}^{+2}$ complexes that induce the formation of amorphous calcium carbonate and decrease incrustations without affecting the permeability of the deposit [6]. It has been reported that the molecular weight distribution (steric effect) and the CMC's concentration modify the size and morphology of the particles [17]. The increase in the concentration of poly(acrylic acid) to $2 \%$ caused the size of the particles to be reduced and their shape to change from plates to quasi-spherical particles which agglomerated.

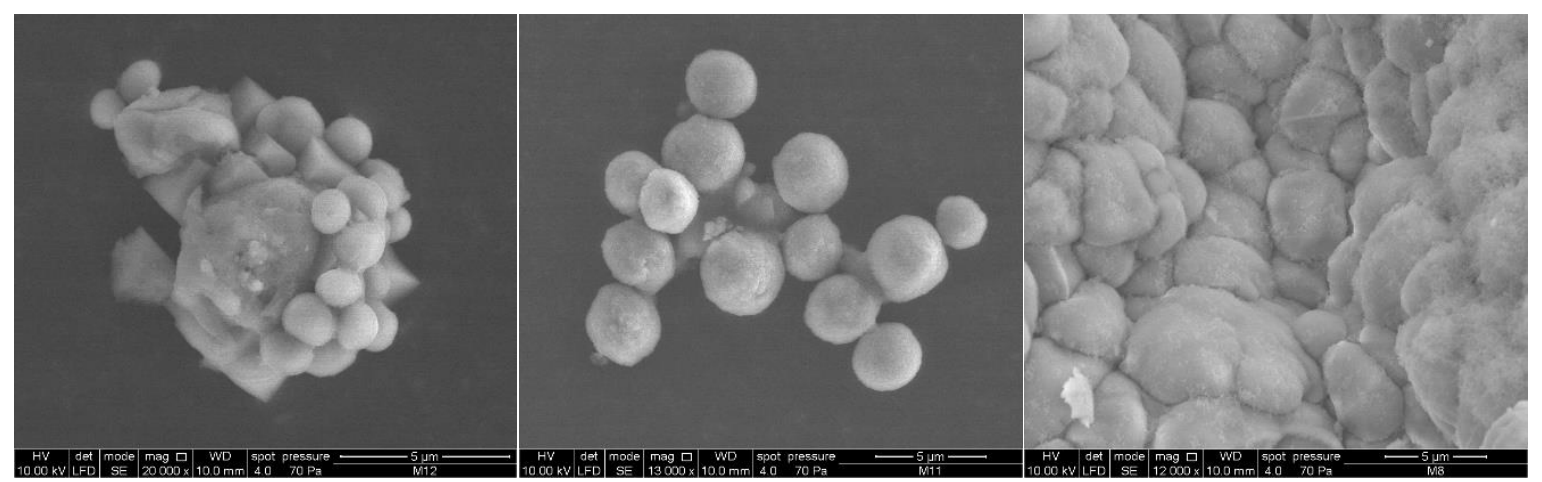

Fig. 8. Micrographs of the $\mathrm{CaCO}_{3}$ crystals obtained when using $2.0 \%$ of inhibitor: (a) $\mathrm{CMC} 1$; (b) $\mathrm{CMC} 2$; (c) poly (acrylic acid).

\section{Conclusion}

The new environmentally friendly scale inhibitor carboxymethyl chitosan (CMC1) synthetized in this study and a commercial carboxymetyl chitosan (CMC2) remove a higher percentage of $\mathrm{Ca}^{+2}$ and $\mathrm{Mg}^{+2}$ ions compared to poly(acrylic) acid.

The concentration of the inhibitors has a significant effect on the distribution of $\mathrm{CaCO}_{3}$ crystal phases and on morphology of the crystallites. 
While at inhibitor concentration of $0.1 \%$, the $\mathrm{CaCO}_{3}$ crystals were mainly of calcite, the distribution of the crystalline phases of $\mathrm{CaCO}_{3}$ was modified by increasing to $2 \%$ of inhibitor. When using the $\mathrm{CMC} 2$ most of the crystals were of vaterite; by using CMC1 the crystals were aragonite, calcite and a small proportion of vaterite, and when poly(acrylic acid) was used, most of the crystals were calcite.

$\mathrm{CaCO}_{3}$ particle size increased when the concentration of the CMC's was increased from $0.1 \%$ to $2 \%$, and their morphology of the crystallites changed from laminar to spherical shape particles. The increase in the poly(acrylic acid) concentration to $2 \%$ caused decrease in the particles size and their shapes changed from plate-like to quasi-spherical particles that formed agglomerates.

\section{Acknowledgments}

The authors would like to thank INTEVEP S.A. for financial support. The chitosan for this study was provided by INNOVAQUITO C.A. and Shanghai Hanshare Industry Co., LTD.

\section{References}

1. BinMerdhah, A. SPE. 2010, 25, 545-552. DOI: https://doi.org/10.2118/141168-PA

2. Mpelwa, M.; Tang, S. Petrol. Sci. 2019, 16, 830-849. DOI: https://doi.org/10.1007/s12182-019-0299$\underline{5}$

3. Rajeev, P.; Surendranathan, A.; Murthy, Ch. J. Mater. Environ. Sci.China 2012, 3, 856-869. ISSN 20282508

4. Moghadasi, J.; Jamialahmadi, M.; Muller-Steinhagen, H.; Sharif, A. SPE. 2004, 86524 DOI: https://doi.org/10.2118/86524-MS

5. Li, X.; Gao, B.; Yue, Q.; Ma, D.; Rong, H.; Zhao, P.; Teng, P. J. Environ Sci.China 2015, 29,124 130. DOI: $10.1016 /$ j.jes.2014.09.027

6. Kumar, S.; K.; Naiya, T.; Kumar, T. J. Petrol. Sci. Eng. 2018, 169, 428-444. DOI: https://doi.org/10.1016/j.petrol.2018.05.068

7. Wang, S.; Xu, X.; Yang, J.; Gao, J. Fuel Process. Technol. 2011, 92, 486-492. DOI: https://doi.org/10.1016/j.fuproc.2010.11.001

8. Doshi, B.; Repo, E.; Heiskanen, J.; Sirviö, J.; Sillanpää, M. Carbohyd. Polym. 2017, 167, 326-336. DOI: https://doi.org/10.1016/j.carbpol.2017.03.064

9. M. de A., R.; Marques, N.; Paulucci, L.; Cunha, J.; Villetti, Castro, B.; Balaban, R. Carbohyd. Polym. 2019, 215, 137-142. DOI: https://doi.org/10.1016/j.carbpol.2019.03.082

10. Zhu, A.; Chan-Park, M.; Dai, S.; Li, L. Colloid Surfaces B. 2005, 43, 143- 149. DOI: https://doi.org/10.1016/j.colsurfb.2005.04.009

11. Ge, H.; Luo, D. Carbohyd. Res. 2005, 340, 1351-1356. DOI: https://doi.org/10.1016/j.carres.2005.02.025

12. Al-Hamzah, A.; Fellows, C.; M.; Desalination. 2015, 359, 22-25. DOI: https://doi.org/10.1016/j.desal.2014.12.027

13. Chen, L.; Du, Y.; Zeng, X. Carbohyd. Res. 2003, 338, 333-340. DOI: https://doi.org/10.1016/S00086215(02)00462-7

14. Farooqui, N.; Sorbie, K.; Boak, L. SPE. 2014, 174214-MS. DOI: https://doi.org/10.2118/174214-MS

15. Xiang, J.; Cao, H.; Warner, J.; Watt, A. Cryst Growth \& Design. 2008, 8, 4583 - 4588 . DOI: https://doi.org/10.1021/cg8006553

16. Kontoyannis, C.; Vagenas, N. Analyst. 2000, 125, 251-255. DOI: https://doi.org/10.1039/a908609i

17. Heywood, B. Chem. Mater. 1994, 6, 311-318. DOI: https://doi.org/10.1021/cm00039a011

18. Muryanto, S.; Bayuseno, A.; Ma'mun, H.; Jotho, M. Procedia Chem. 2014, 9, 69 - 76. DOI: https://doi.org/10.1016/j.proche.2014.05.009 